\title{
Challenges lie ahead for MTS in the Aotearoa public sphere
}

JOANNA PAUL

Ngai te Rangi, independent television producer

\section{Mo ratou, ma matou, ma koutou, ma tatou For them, for us, for everyone}

S THE Maori Television Service (MTS) celebrates its first year on
air, it is easy to forget the long and at times painful struggle to get
there, the aspirations of those who have worked in, consulted, wrote, and protested their way through the various incarnations of Maori broadcasting. The incarnations include Maori programming on mainstream television, Aotearoa Television, the Electoral College, Te Manu Aute, Nga Aho Whakaari, MTS legislation and the exhaustive process of building a new channel for all New Zealanders. We pay homage to those who have gone before and their passion to see Maori Television for and by Maori, to hear our Reo, tell our stories and to bring our way of life to all New Zealanders.

Hutia te rito o te harakeke

Kei hea te komako e ko e?

Whataerangaitia. Tirohia ki uta, tirohia ki tae,

A, ui mai ki a au, he aha mea nui o te au?

Maku e ki atu

He tangata, he tangata, he tangata

What is the most important thing to me

The people, the people, the people

It is with great pride that I note my own contribution to the newest channel in 
New Zealand's burgeoning media market and the rest of the team who launched it all only a short year ago in March 2004. The Maori Television Service is now housed in a purpose-built building in Newmarket, central Auckland - a unique interactive open studio environment. A truly beautiful creation that swells one's heart with pride once you step inside its graceful kuaha, and a channel that is making a significant contribution to broadcasting in Aotearoa. Finally we are seeing Maori faces in prime time and hearing the language at all times with programming that is targeted to our growing audience of language users and learners.

Maori Television is unique in many ways. Its origins lie in a Privy Council decision to see Maori Language revitalised and retained within the broadcasting paradigm. It has its own legislation, the Maori Television Service Act, and boasts a board whose members are chosen by both the government and an electoral college representing Maori interests. This working partnership is the first of its kind for the industry. About 100 people are employed within the service. They have their own super production facilities, studio, network services and while receiving only a small portion of public funding (by mainstream television standards) transmit a reputable news and current affairs service as well as a full range of local and international entertainment educational and informational television. It is public service broadcasting at its very best. In an age when the Public Service Broadcasting Charter is difficult to see sometimes on mainstream television, Maori Television continues to put out some of the most original and entertaining local production in both languages and thus reflect a predominantly New Zealand reality.

This channel has the unique ability to 'think outside the square' and has changed the face of the small screen as we know it. It also has the facility to reshape the industry for Maori practitioners today and for generations to come. Maori had laboured long under a system that had marginalised us, our images, our voices and our concerns. As a new network we have the prospect to change the paradigm and reflect ourselves, not someone else's version of who we should be. Many more Maori have been given the chance to make programmes to watch at times that are appropriate to us, not just on an early weekend morning or news in the late afternoon.

But its progress has not been without casualties, many of which have been played out by a hungry tabloid press who seem all too eager to see Maori Television fail. There are a handful of Pakeha journalists who appear 
to have catapulted their careers on the shaky and at times slanderous ground of MTS stories and the related production industry. These are journalists who have neither bothered to look beyond their dodgy 'sources' playing out their own personal vendettas or inspect their own small-minded ethnocentric prejudices; or indeed investigated industry practice to expose some of the anomalies Maori television must endure every day as a broadcaster.

Maori Television has also encouraged the establishment of several new production houses and caused some of the more established houses to triple in size. This rapid acceleration of small business has big pluses and similarly big minuses. Problems include some companies struggling to meet the demands of the new station, or deliver quality programming on time and on budget. The new station has created the conditions for the empowerment of Maori to the industry and also has to cope with the many who have not taken the time to learn the tools and time-honoured techniques of good television making. Instead, the latter become overnight producer/directors and often flounder as a result. From a time when most Maori within the industry had been working in children's, news or magazine programming, producers now have to deliver a much broader range of genres without the support of years of experience. They also do not enjoy the same time to make mistakes, funding and forgiveness that Pakeha broadcasters have had. There is an expectation we must be able to do it all and NOW or we are wasting public funds and people's precious time. Not only must Maori endure the unfairness of this situation but also the ignominy of potential failure with budgets that are sometimes less than half of those enjoyed by Pakeha production houses making the same kind of programmes for mainstream television.

The news service has increased demand for bilingual journalists and provided another perspective on the top stories of the day. ${ }^{1}$ This was always seen as a critical part of MTS's public broadcasting obligation. It is not just the Maori cultural insight it provides but the perspective one can only gather when working the stories in one's own language. Maori Television was also set up with subtitling facilities to grow its services and win a greater audience.

We already know eight out of ten of us are aged under 40 and six out of 10 are still at school. We are a young population. Maori language surveys tell us one-third of us are learning Te Reo and another third are speaking it. There is a small percentage of native language speakers in New Zealand and many 
of them are over the age of 60 . However the proliferation of kohanga, kura and waananga is proof enough of Maori commitment to ourselves and to our language and culture. From a programming point of view, this leads the way to channel positioning. But although we are clearly a 'youth oriented, adult acceptable' primary television demographic we can't afford to just commit to the 'getting bums on seats' mentality that drives many mainstream media and advertising revenue. There is only one Maori Television channel and it has the difficult job of seeing itself as 'all things to all people'.

On the one hand there are those who would argue that success lies in capturing the tough youth market, where the numbers lie, and therefore unashamedly programming for the 18- 39 audience; understanding the primary market, their needs and desires, likes and dislikes and reflecting in much the same way as radio has successfully done. Others would argue that Maori are best served by predominantly Maori language programming across a range of genres, being aspirational rather than reflective for its population. In a small market like New Zealand, where Maori are still under-represented in prime times, it may be inevitable that MTS ends up becoming all things to all people, but does this bode well for the long term future of MTS ?

\section{The future}

At present, the Maori Television Service relies almost entirely on public funds through Te Mangai Paho. It does not, as has been reported, receive all the reported \$50million worth of funds from Te Mangai Paho as these dollars pay for Raio, administration, not to mention a significant portion being shared with programmes being made for TVNZ, TV3 and perhaps even Prime TV now. When I was with MTS, it was still ineligible for any New Zealand on Air funds and even with a reduced number of on-air hours we still had a large number of repeat hours to make up the schedule. I note that Maori TV enjoys some new ads but how long will successive governments continue to uphold and fund such a service? Will the funding increase to levels that assure a diversity of programme making and ensure that the service grows in air hours? Will the training programmes for Maori Language practitioners be instigated and funded? Will Maori small business receive the assistance, support, mentoring and development required to move into a larger production arena? These are only some of the difficult questions that Maori Television faces in election year. Whatever the answers, it would most assuredly be a travesty to 
THE INDIGENOUS PUBLIC SPHERE

lose the new face of broadcasting in Aotearoa; when it appears you have no doubt you are seeing and hearing the tangata whenua of this country and we are all the richer for it.

\section{Note}

${ }^{1}$ According to The New Zealand Herald (26 March 2005), a surge in enrolments in Maori media studies at Auckland University of Technology has been just one sign of burgeoning opportunities for Maori in film and television. Julian Wilcox, who teaches at AUT as well as presenting at MTS, says: 'Simply put, there are not enough people out there with language skills who are able to critique in a Maori way and get out and do Maori language programmes.'

Joanna Paul was one of the pioneers of the Maori Television Service (MTS) and was the inaugural general manager of programming, production and acquisitions when the new channel was launched in March 2004. She is now an independent television producer. 
Copyright of Pacific Journalism Review is the property of Auckland University of Technology and its content may not be copied or emailed to multiple sites or posted to a listserv without the copyright holder's express written permission. However, users may print, download, or email articles for individual use.

http://Mww.aut.ac.nz/depts/commstud/journ/pjrsubs.shtml 